BACKGROUND: Protein-energy malnutrition (PEM) results from food insufficiency as well as from poor social and economic conditions. Development of PEM is due to insufficient nutrition. Children with PEM lose their resistance to infections because of a disordered immune system. It has been reported that the changes occurring in mediators referred to as cytokines in the immune system may be indicators of the disorders associated with PEM.

Aims : To determine the concentrations of pro-inflammatory cytokines in children with PEM, and to find out whether there was an association with the clinical presentation of PEM.

Methods: The levels of serum total protein, albumin, tumour necrosis factor- $\alpha$, and interleukin-6 were measured in 25 patients with PEM and in 18 healthy children as a control group. PEM was divided into two groups as kwashiorkor and marasmus. The kwashiorkor group consisted of 15 children and the marasmus group consisted of 10 children.

Results : Levels of serum total protein and albumin of the kwashiorkor group were significantly lower than both the marasmus group and controls $(p<0.05)$. In view of tumour necrosis factor- $\alpha$ levels, there was no difference between groups $(p>0.05)$. While levels of interleukin- 6 in both the marasmus group and the kwashiorkor group were significantly higher compared with controls $(p<0.05)$, there was no significant difference between the groups of marasmus and kwashiorkor $(p>0.05)$.

Conclusions : It was observed that the inflammatory response had increased in children with malnutrition.

Key words: Malnutrition, Tumour necrosis factor- ${ }^{-} \alpha$, interleukin-6.

\section{Pro-inflammatory cytokines in Turkish children with protein-energy malnutrition}

\author{
Haluk Dülger ${ }^{1, C A}$, Mehmet Arik', \\ M. Ramazan Sekeroğlu', Mehmet Tarakçioğlư ${ }^{2}$, \\ Tevfik Noyan', Yaşar Cesur ${ }^{3}$ and Ragip Balahoroğlu'
}

${ }^{1}$ Department of Biochemistry and ${ }^{3}$ Department of Pediatry, School of Medicine, University of Yüzüncü Yil, Tip Fakültesi, Biyokimya Anabilim Dali, Maras Caddesi, 65300 Van, Turkey, and ${ }^{2}$ Department of Biochemistry, School of Medicine, University of Gaziantep, Gaziantep, Turkey

\author{
${ }^{\mathrm{CA}}$ Corresponding Author \\ Tel/fax: +90 4322167462 \\ E-mail: halukdulger@yahoo.com
}

\section{Introduction}

Protein-energy malnutrition (PEM), the most widespread pattern of malnutrition, occurs most frequently in infants and young children as a result of a coincident lack of protein and calories, and it is commonly associated with infection. Most authors have described the disease as occurring in three clinical types, with marasmus at one end of the spectrum kwashiorkor at the other end, and marasmic kwashiorkor as an intermediate form. ${ }^{1}$

Marasmus and kwashiorkor are the two primary clinical manifestations of diets deficient in energy and protein. Marasmus is characterized by wasting and decreased physical activity but, with stimulation, mental status and appetite are relatively normal. $^{2}$ Kwashiorkor, including marasmic kwashiorkor, is characterized by massive oedema of the hands and feet, profound irritability, anorexia, a desquamative rash, hair discolouration, and a large fatty liver. ${ }^{3}$
The factors determining whether kwashiorkor or marasmus develops remain unknown. Marasmus has been described as an adaptation to inadequate energy and protein intake, and kwashiorkor as a dysadaptation. ${ }^{4}$

Chronic infections, such as infection with HIV and tuberculosis, pathologically compromise the nutritional status and contribute to the global burden of childhood malnutrition, particularly in Africa. Malnutrition is associated with a decrease in the rates of whole-body protein synthesis and breakdown. ${ }^{5}$ This is believed to be an adaptive mechanism to conserve energy and amino acids when they are in scarce supply. ${ }^{6}$ Previous reports of protein kinetics in childhood malnutrition did not distinguish between children with kwashiorkor and those with marasmus. During the physiologic stress of acute infection, the rate of whole-body protein turnover increases. ${ }^{7}$ This is an appropriate response to help the individual respond successfully to the infection. The increase in 
Table 1. Antropometric measurements of groups and controls

\begin{tabular}{lccc}
\hline & $\begin{array}{c}\text { Control } \\
(n=18)\end{array}$ & $\begin{array}{c}\text { Kwashiorkor } \\
(n=15)\end{array}$ & $\begin{array}{c}\text { Marasmus } \\
(n=10)\end{array}$ \\
\hline Age (years) & $2.61 \pm 1.64$ & $1.73 \pm 1.22$ & $2.30 \pm 1.42$ \\
Length (cm) & $85.56 \pm 17.86$ & $64.33 \pm 6.15^{*}$ & $61.85 \pm 9.38^{*}$ \\
Weight (g) & $12180 \pm 4276$ & $5133 \pm 1846^{*}$ & $5200 \pm 2097^{*}$ \\
\hline
\end{tabular}

Data presented as mean $\pm \mathrm{SD} .{ }^{*} p<0.001$.

the rate of protein breakdown is presumed to provide amino acids for the synthesis of acute phase proteins. $^{8}$

The 'radical theory' proposed by Golden and Ramdath $^{9}$ postulates that the imbalance between the production of free radicals and their neutralization by scavengers plays an important role in the development of the kwashiorkor syndrome. These radicals, which are products of the inflammatory response, generate peroxides, particularly in cell membranes. ${ }^{9}$ Prostaglandin $\mathrm{E}_{2}$ and cysteinyl leukotrienes, which are powerful agents in the inflammatory response, increase in PEM upon in vitro stimulation. ${ }^{10}$

The aims of the present study were to determine the concentrations of pro-inflammatory cytokines in children with PEM, and to find out whether there was an association with the clinical presentation of PEM.

\section{Material and methods}

A total of 43 children (age range, 1-5 years) living in Van, Turkey, were recruited. Twenty-five of these subjects were suffering from different degrees of PEM and fulfilled the criteria for PEM detailed in the classification of the Wellcome Trust Working Party. ${ }^{1}$ Of these, 15 children had kwashiorkor and 10 had marasmus. They were admitted at the Yüzüncü Yil University, School of Medicine Hospital, Van. Eighteen children who had no sign of malnutrition were recruited from the community and used as control subjects. All subjects were of the same socio-economic background. None of these children were using either micronutrient supplementation or any medication.
A total of $5 \mathrm{ml}$ of venous blood was drawn from each subject. Blood samples were then centrifuged at 2000 r.p.m. for $10 \mathrm{~min}$ in a refrigerated centrifuge to separate serum samples from the cells. Serum samples were stored at $-70^{\circ} \mathrm{C}$ in plastic tubes until analysis.

Serum interleukin (IL)-6 and tumour necrosis factor (TNF)- $\alpha$ were measured using the commercial IMMULITE kits, which are a solid-phase, two-site chemiluminescent immunometric assay (Immulite, DPC, Los Angeles, CA 90045, USA). Total protein and albumin were determined in the serum by routine methods using colourimetric methods on a Roche modular autoanalyser (Roche modular $\mathrm{P}+\mathrm{P}$ autoanalyser, Tokyo, Japan).

Statistical analysis

Subjects with either kwashiorkor or marasmus were compared with non-malnourished controls. Means and standard deviations of means were calculated, and differences between means were assessed by one-way analysis of variance. Between-groups significant differences were indicated by the post-hocTukey test.

\section{Results}

The anthropometric measurements of the study subjects are presented in Table 1 . There were no differences in the mean age of patients and the control group $(\phi>0.05)$. Contrary to this, the length and weight of both the marasmic and kwashiorkor groups were lower compared with the control group $(p<0.001)$ (Table 1$)$.

The serum total protein, albumin, TNF- $\alpha$ and IL-6 levels of the control group and the patient groups with PEM are presented in Table 2. While total protein and

Table 2. Levels of total protein, albumin, TNF- $\alpha$, and IL-6 of PEM and controls

\begin{tabular}{lrcr}
\hline & $\begin{array}{c}\text { Control } \\
(\mathrm{n}=18)\end{array}$ & $\begin{array}{c}\text { Kwashiorkor } \\
(\mathrm{n}=15)\end{array}$ & $\begin{array}{c}\text { Marasmus } \\
(\mathrm{n}=10)\end{array}$ \\
\hline Total protein $(\mathrm{g} / \mathrm{dl})$ & $6.60 \pm 0.80$ & $5.76 \pm 0.61^{\mathrm{a}, \mathrm{b}}$ & $6.66 \pm 1.27$ \\
Albumin $(\mathrm{g} / \mathrm{dl})$ & $3.91 \pm 0.39$ & $3.13 \pm 0.60^{\mathrm{a}, \mathrm{c}}$ & $3.77 \pm 0.98$ \\
TNF- $\alpha(\mathrm{pg} / \mathrm{ml})$ & $14.71 \pm 7.84$ & $16.66 \pm 5.02$ & $16.80 \pm 4.69$ \\
IL-6 $(\mathrm{pg} / \mathrm{ml})$ & $3.55 \pm 1.57$ & $18.45 \pm 9.30^{\mathrm{d}}$ & $15.46 \pm 10.73^{\mathrm{d}}$ \\
\hline
\end{tabular}

Data presented as mean \pm SD. ${ }^{a, b, c} p<0.05,{ }^{d} p<0.001$; a and $d$ refer to comparison with control group, and $b$ and $c$ refer to the degree of significance of comparison between the kwashiorkor and marasmus groups. 
albumin levels were lower in patients with kwashiorkor $(p<0.05)$, there were no differences in these traits between the control and the marasmus groups $(p$ $>0.05)$. Whereas there were no differences in TNF- $\alpha$ concentrations between the control group and the groups with PEM $(p>0.05)$, IL-6 levels of the groups with kwashiorkor and marasmic were significantly higher than those of the control group $(p<0.001)$.

\section{Discussion}

Rates of whole-body protein breakdown and protein synthesis are greater in children with marasmus than in those with kwashiorkor during acute infection. It has been reported that children with marasmus appropriately reduce their rates of whole-body protein turnover to conserve energy and amino acids. ${ }^{5}$ Previous studies suggest that rates of whole-body protein breakdown and synthesis can increase in children with marasmus under the physiologic stress of infection. ${ }^{3}$ In fact, infections have been postulated to be a trigger for oedema formation in kwashiorkor. ${ }^{9}$ In a study performed on children with PEM, Manary et $a l{ }^{3}$ reported that albumin and globulin levels were lower in kwashiorkor patients compared with marasmic ones; nevertheless, they failed to demonstrate this fact's relationship with response to the acute phase. In the present study, total protein and albumin levels were significantly lower in kwashiorkor children compared with both the marasmic and control groups. This explained the clinically observed oedema in the kwashiorkor group.

The increase in the inflammatory indexes may be explained by concomitant infections, which are frequently found in PEM patients. ${ }^{11}$ Production ofTNF$\alpha$, IL-6, and IL-1-like activity by stimulated blood cells in vitro is reduced in malnourished children. In rats, IL1 and TNF- $\alpha$ production of peritoneal macrophages, Kupffer cells, or alveolar macrophages is not different between animals with PEM and control animals. ${ }^{12}$ Diminished production of endogenous pyrogens has been shown previously in animals with PEM and in PEM patients. ${ }^{12,13}$ Sauerwein et al ${ }^{11}$ found that serum IL-6, soluble tumor necrosis factor receptor (sTNFR)p55, sTNFR-p75 and C-reactive protein (CRP) were high in PEM, especially in the group having kwashiorkor, compared with the control group, but soluble IL-6 receptor (sIL-6R) and IL-1 receptor antagonist (IL-1Ra) concentrations were not different from healthy children. In the same study, it was reported that, regardless of infection, serum IL-6, sTNFR-p55 and sTNFR-p75 concentrations were high in the kwashiorkor group. The findings of the present study are in agreement with the results of the afore- mentioned study. Although IL-6 levels in the kwashiorkor form of PEM were high compared with those of marasmus, the differences were not significant. The fact that IL-6 was high in kwashiorkor leads to the thought that IL-6 may have a role in oedema parthenogenesis. The presence of a positive correlation between the increase in body mass index and subcutaneous fat tissues and the release of $\mathrm{TNF}_{-} \alpha$ was demonstrated in recent studies. ${ }^{14,15}$ In the current study, there were no differences in $\mathrm{TNF}_{-} \alpha$ levels between groups. The absence of differences in TNF- $\alpha$ concentrations in comparison with the control groups could be caused by malnutrition-related low body mass index and decreased subcutaneous fat tissue in these groups. It was concluded that TNF- $\alpha$ and IL- 6 concentrations alone could not be an indicator for diagnosis of PEM; however, the determination of serum IL-6 concentrations could confirm the diagnosis.

\section{References}

1. Abo-Hussein SA, Hussein ZM, Farag SI, Shebl SS, El-Melegy S, Akhnoukh $S$. A profile of ammonia-urea values in blood and cerebrospinal fluid in children with protein energy malnutrition. J Trop Med Hygiene 1984; 87: 237-240.

2. McLaren DS, Pellett P, ReadW. A simple scoring system for classifying the severe forms of protein-calorie malnutrition of early childhood. Lancet 1967; 1: 533-535

3. Manary MJ, Broadhead RL, Yarasheski KE. Whole-body protein kinetics in marasmus and kwashiorkor during acute infection. Am J Clin Nutr 1998; 67: 1205-1209.

4. Rao KSJ. Evolution of kwashiorkor and marasmus. Lancet 1974; 1: 709-711.

5. Golden MHN, Waterlow JC, Picou D. Protein turnover, synthesis and breakdown before and after recovery from protein-energy malnutrition. Clin Sci 1977; 53: 473-477.

6. Waterlow JC. Metabolic adaptation to low intakes of energy and protein Annu Rev Nutr 1986; 6: 495-526.

7. Long CL, Jeevanandam M, Kim BM, Kinney JM. Whole body protein synthesis and catabolism in septic man. Am J Clin Nutr 1977; 30: 1340-1344.

8. Reeds PJ, Fjeld CR, Jahoor F. Do the differences between the amino acid compositions of acute-phase and muscle proteins have a bearing on nitrogen loss in traumatic stress? J Nutr 1994; 124: 906-910.

9. Golden MHN, Ramdath D. Free radicals in the pathogenesis of kwashiorkor. Proc Nutr Soc 1987; 46: 53-68.

10. Mayatepek E, Becker K, Gana L, Hoffman GF, Leichsenring M. Leukotrienes in the pathophysiology of kwashiorkor. Lancet 1993; 342 958-960.

11. Sauerwein RW, Mulder JA, Mulder L, et al. Inflammatory mediators in children with protein-energy malnutrition. Am J Clin Nutr 1997; 65: 1534-1539.

12. Bradley SF, Vibhagool A, Kunkel SL, Kauffman CA. Monokine secretion in aging and protein malnutrition. J Leukoc Biol 1989; 45: 510-514.

13. Kauffman CA, Jones PG, Kluger MJ. Fever and malnutrition: endogenous pyrogen/interleukin-1 in malnourished patients. Am J Clin Nutr 1986; 44: 449-452.

14. Bullo M, Garcia-Lorda P, Peinado-Onsurbe J, Hernandez M, Del Castillo D, Argiles JM, Salas-Salvado J. TNF alpha expression of subcutaneous adipose tissue in obese and morbid obese females: relationship to adipocyte LPL activity and leptin synthesis. Int J Obes Relat Metab Disord 2002; 26: 652-658.

15. Laimer M, Ebenbichler CF, Kaser S, et al. Markers of chronic inflammation and obesity: a prospective study on the reversibility of this association in middle-aged women undergoing weight loss by surgical intervention. Int J Obes Relat Metab Disord 2002; 26: 659-662.

Received 9 September 2002

Accepted 3 October 2002 


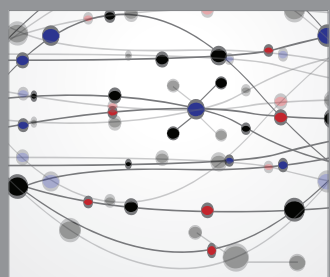

The Scientific World Journal
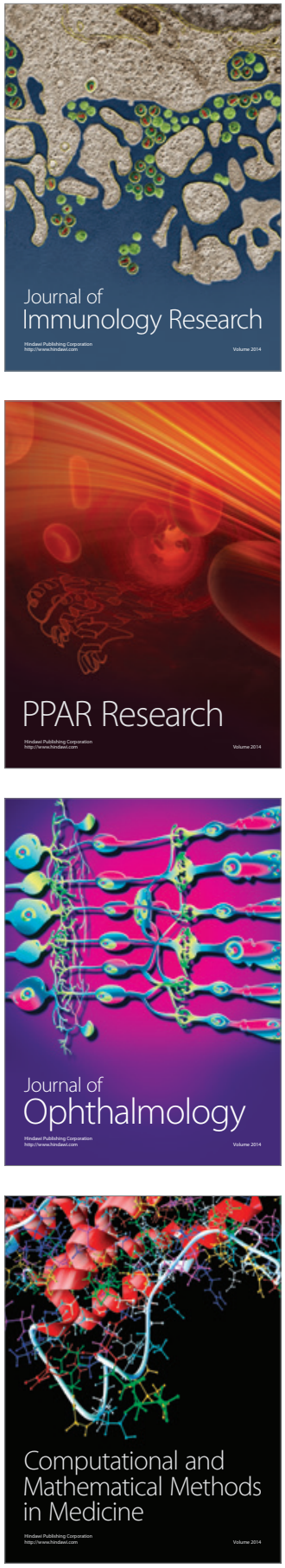

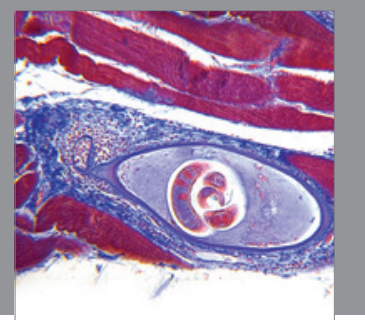

Gastroenterology

Research and Practice
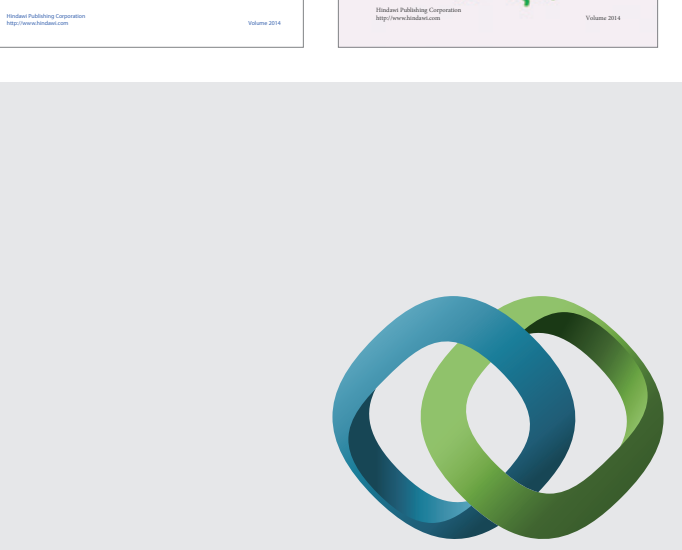

\section{Hindawi}

Submit your manuscripts at

http://www.hindawi.com
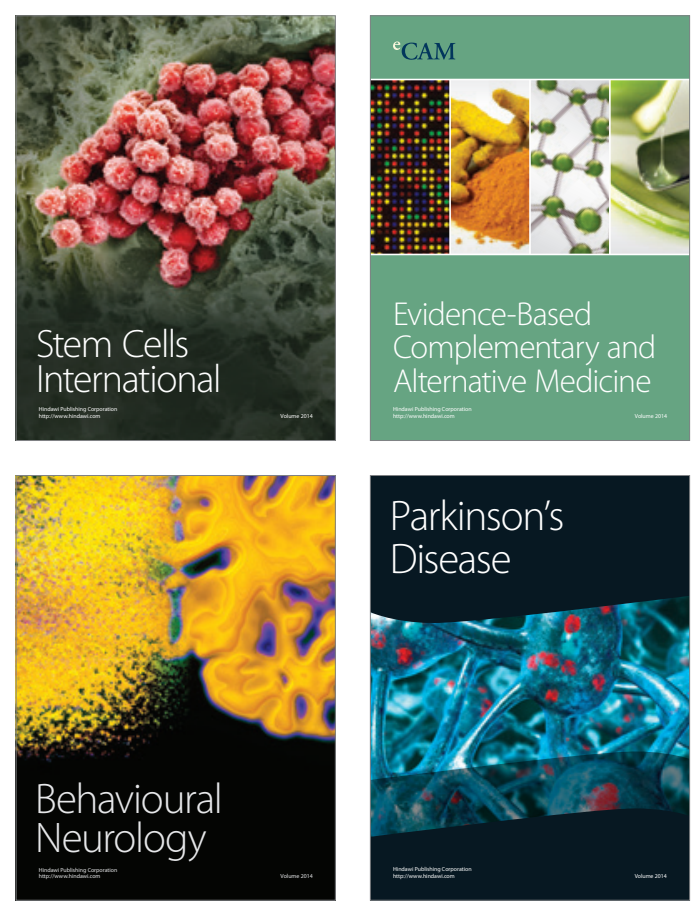

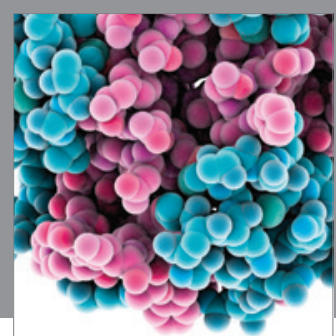

Journal of
Diabetes Research

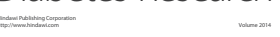

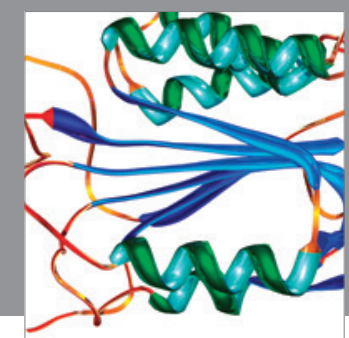

Disease Markers
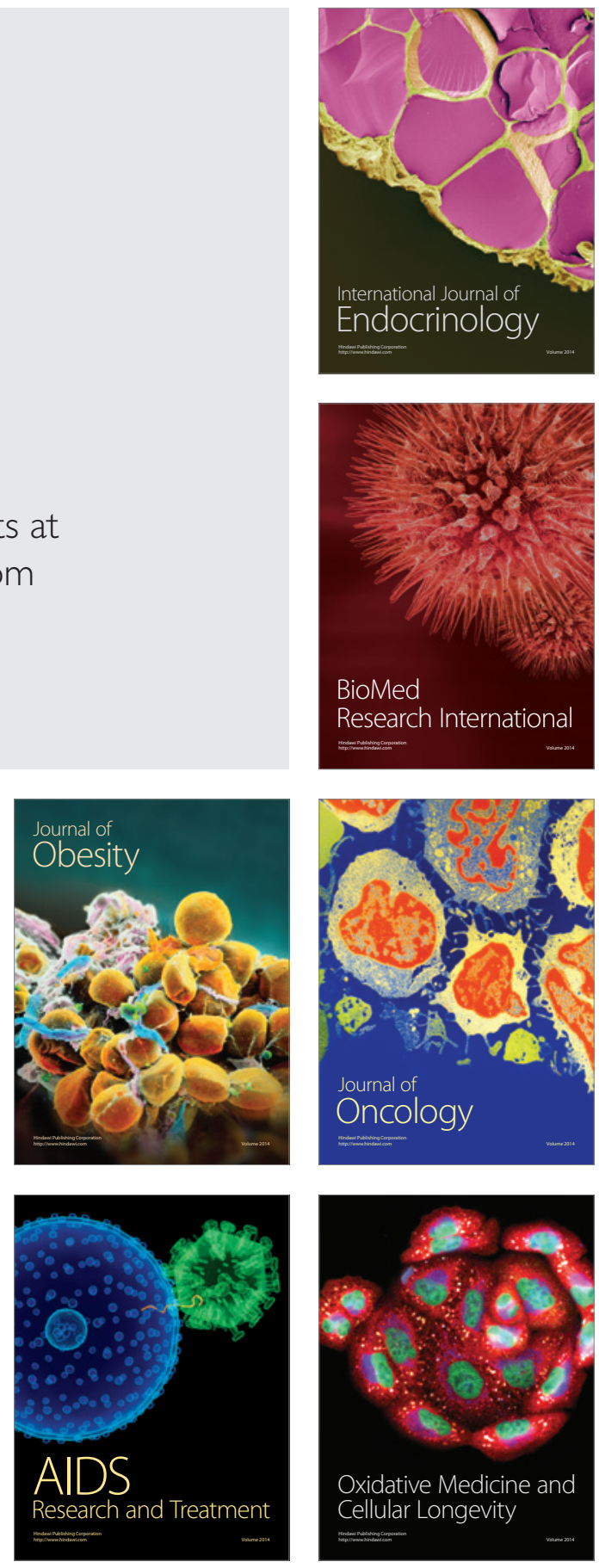